\title{
Comparison of Adrenocorticotropin and Adrenal Steroid Responses to Corticotropin-Releasing Hormone Versus Metyrapone Testing in Patients with Hypopituitarism
}

\author{
LINDA RIDDICK, GEORGE P. CHROUSOS, SUSAN JEFFRIES, AND SONGYA PANG \\ Department of Pediatrics, University of Illinois, College of Medicine at Chicago, Chicago, \\ Illinois 60612 /L.R., S.J., S.P./, and National Institutes of Health, Developmental Endocrinology \\ Branch, Bethesda, Maryland 20892 /G.P.C.I
}

\section{ABSTRACT}

We compared the responses of ACTH and cortisol (F) to corticotropin-releasing hormone (CRH) administration (ovine $1 \mu \mathrm{g} / \mathrm{kg}$ i.v. bolus) with the responses of urinary 17-OH corticosteroids (17-OHCS) and serum deoxycorticosterone (DOC) to metyrapone administration $(450 \mathrm{mg} /$ $\mathrm{m}^{2} /$ dose every $4 \mathrm{~h} \times$ seven doses) in 16 hypopituitary patients. Glucocorticoid therapy for these patients was withheld for a minimum of $3 \mathrm{wk}$ before testing. The CRH test was performed $3 \mathrm{~d}$ before or $3 \mathrm{wk}$ after the metyrapone test was used to diagnose the ACTH reserve status. In nine ACTH-intact hypopituitary patients (postmetyrapone $17-\mathrm{OHCS}>12.2 \mu \mathrm{mol} / \mathrm{m}^{2} / \mathrm{d} ;$ DOC $\geq 11.5$ $\mathrm{nmol} / \mathrm{L})$, the peak F (497-773 nmol/L) and ACTH $(5.2-22$ $\mathrm{pmol} / \mathrm{L}$ ) responses to $\mathrm{CRH}$ stimulation were similar to those of normal subjects $(\mathrm{F}$ peak $=554-993 \mathrm{nmol} / \mathrm{L}$ and ACTH peak $=6-25 \mathrm{pmol} / \mathrm{L}$ at $15-60 \mathrm{~min})$. In one patient with partial ACTH deficiency (postmetyrapone 17-OHCS $=10.5 \mu \mathrm{mol} / \mathrm{m}^{2} / \mathrm{d} ;$ DOC $\left.=6 \mathrm{nmol} / \mathrm{L}\right)$, the peak $\mathrm{F}$ response was low and delayed $(246 \mathrm{nmol} / \mathrm{L}$ at $180 \mathrm{~min})$ and the peak ACTH response was normal $(7 \mathrm{pmol} / \mathrm{L})$. Six severely ACTH-deficient patients (postmetyrapone 17OHCS $<5.4 \mu \mathrm{mol} / \mathrm{m}^{2} / \mathrm{d} ;$ DOC $\leq 3.4 \mathrm{nmol} / \mathrm{L}$ ) had a low $\mathrm{F}$

Distinct patterns of hypothalamic-pituitary-adrenal axes function during $\mathrm{CRH}$ stimulation have been characterized in Cushing's disease or syndrome and in primary adrenal insufficiency (1-6). Hyperresponse of ACTH and F in Cushing's disease and low or minimal response of $\mathrm{ACTH}$ and $\mathrm{F}$ in Cushing's syndrome to $\mathrm{CRH}$ administration assisted in the differentiation of etiology (1-5). The CRH stimulation test has also been proposed as a means of distinguishing either

Received September 8, 1993; accepted March 18, 1994.

Correspondence and reprint requests: Dr. Songya Pang. University of Illinois, Department of Pediatrics (M/C 856), 840 South Wood St., Chicago, IL 6(6) I2.

Supported in part by USPHS Grant ROI HD 24360, a grant from Washington Square Health Foundation at Chicago, and a biomedical research grant from the University of Illinois College of Medicine. Chicago. response at $15-90 \mathrm{~min}$ in all, with a delayed rise in three at $120-180 \mathrm{~min}$ in response to CRH administration, whereas ACTH responses were variable: absent or low, normal, delayed, or persistently exaggerated. In conclusion, the CRH-stimulated $\mathrm{F}$ response pattern in hypopituitary patients was comparable to the urinary $17-\mathrm{OHCS}$ and serum DOC response to metyrapone administration. Thus, $F$ response pattern to $\mathrm{CRH}$ was useful in the evaluation of ACTH reserve in hypopituitary patients. ACTH response to CRH in ACTH-deficient patients was not consistently useful for ACTH reserve evaluation because of the variable response possibly resulting from a different etiology (hypothalamus versus pituitary) of ACTH deficiency. (Pediatr Res 36: 215-220, 1994)

\author{
Abbreviations \\ CRH, corticotropin-releasing hormone \\ F, cortisol \\ 17-OHCS, 17-hydroxycorticosteroid \\ DOC, deoxycorticosterone \\ DDAVP, desmopressin
}

primary or secondary adrenal insufficiency due to hypothalamic or pituitary dysfunction (6-10). However, no comparison has been reported between the ACTH and adrenocortical steroid response to the CRH stimulation test versus a standard ACTH provocative test, via metyrapone administration, in patients with hypopituitarism.

The aim of this study was to investigate whether the CRH stimulation test would accurately reflect pituitaryadrenal function in the evaluation of $\mathrm{ACTH}$ reserve compared with metyrapone testing in patients with one or more pituitary hormone deficiencies. The responses of plasma $\mathrm{ACTH}$ and $\mathrm{F}$ to $\mathrm{CRH}$ were therefore compared with hormonal responses to oral metyrapone administration in patients with hypopituitarism. 


\section{METHODS}

All studies were performed under institutionally approved protocols after informed consent was obtained from normal volunteer subjects, patients, their parents or legal guardians, and, whenever possible, from the minors if they understood the test purpose.

Patients. Sixteen patients with proven single or multiple pituitary hormone deficiencies were studied (Table 1). The hypopituitary subjects, eight females and eight males, ranged in chronologic age from 2 to $18 \mathrm{y}$. Five patients had isolated growth hormone deficiency, and 11 had multiple hormone deficiencies, including growth hormone, TSH, LH, FSH, and antidiuretic hormone. The treatment status of hypopituitarism in these patients is indicated in Table 1. Eight patients were receiving growth hormone therapy at the time of testing. Two patients with antidiuretic hormone deficiency were treated with DDAVP $(5-10 \mu \mathrm{g} / \mathrm{d})$ in doses that resulted in normal electrolyte and water balance. Eight patients received L-thyroxine $(75-150 \mu \mathrm{g} / \mathrm{d})$ and were euthyroid at the time of testing. Four patients received occasional hydrocortisone therapy only for stressful events; however, no hydrocortisone was given at least $8 \mathrm{wk}$ before testing in these patients. One patient received maintenance hydrocortisone therapy $(25 \mathrm{mg} / \mathrm{d})$, which was discontinued 3 wk before testing. All patients with hypopituitarism had metyrapone and $\mathrm{CRH}$ stimulation tests. Control subjects were six healthy female and three male volunteers, aged 15-45 y, who underwent CRH stimulation testing only.

Metyrapone provocative test. ACTH reserve secretory capacity was determined by the response of urinary 17 OHCS excretion and serum DOC to oral metyrapone administration $\left(450 \mathrm{mg} / \mathrm{m}^{2} /\right.$ dose every $4 \mathrm{~h}$ for seven doses) (Table 1). Urine samples were collected for $24 \mathrm{~h}$ preceding, during, and for $24 \mathrm{~h}$ after metyrapone administration for the determination of urinary 17-OHCS excretion. Blood samples were obtained for DOC in the morning of the baseline day and again in the morning after the 7th dose of metyrapone.

Definition of ACTH reserve status. The patients whose urinary $17-\mathrm{OHCS}$ excretion rose to greater than 2.5 times the baseline levels, demonstrated a marked rise in serum DOC $(11.5-85.3 \mathrm{nmol} / \mathrm{L})$, or both after seven doses of metyrapone were defined as having adequate ACTH reserve using a normal response reported previously (cases $1-9$, Table 1) $(11,12)$. The patients whose urinary $17-$ OHCS and serum DOC $(<0.3-3.4 \mathrm{nmol} / \mathrm{L})$ responses to metyrapone were minimal or absent were classified as having severe ACTH deficiency (cases 11-16, Table 1). Partial ACTH deficiency was diagnosed in one patient (case 10, Table 1) based on the modest rise in urinary 17-OHCS and serum DOC $(6 \mathrm{~nm} / \mathrm{L})$ levels, which were greater than those in the severe ACTH deficiency patients but lower than in ACTH-intact patients.

CRH stimulation test. The test was conducted at 1300 $1600 \mathrm{~h}$ after a half-hour rest in the recumbent position and at least $3 \mathrm{~d}$ before or $3 \mathrm{wk}$ after metyrapone testing. A slow i.v. bolus of $1 \mu \mathrm{g} / \mathrm{kg}$ of ovine CRH was given over a few minutes. Two subjects experienced short-lasting hot flashes within a few minutes after $\mathrm{CRH}$ administration. Blood samples were drawn at $-15,0,15,30,60,90$, 120,150 , and $180 \mathrm{~min}$ for measurement of serum ACTH and F. In young children, blood samples were collected less frequently. Blood samples for measurement of

Table 1. Clinical and hormonal data in patients with hypopituitarism at ACTH resenve evaluation*

\begin{tabular}{|c|c|c|c|c|c|c|c|c|c|}
\hline \multirow[b]{2}{*}{ Case } & \multirow[b]{2}{*}{ Sex } & \multirow{2}{*}{$\begin{array}{l}\text { Age } \\
(y)\end{array}$} & \multirow[b]{2}{*}{ Etiology } & \multirow[b]{2}{*}{ Hormone deficiency } & \multirow[b]{2}{*}{ Treatment } & \multicolumn{2}{|c|}{$\begin{array}{c}\text { Urinary } 17-\mathrm{OHCS} \\
\left(\mu \mathrm{mol} / \mathrm{m}^{2} / 24 \mathrm{~h}\right)\end{array}$} & \multicolumn{2}{|c|}{ Serum DOC $(\mathrm{nmol} / \mathrm{L})$} \\
\hline & & & & & & Baseline & Postmetyrapone & Baseline & Postmetyrapone \\
\hline 1 & F & 2 & $\begin{array}{l}\text { Postremoval } \\
\text { craniopharyngioma }\end{array}$ & $\mathrm{GH}$ & GH & 0.14 & 18.9 & & 30.9 \\
\hline 2 & $\mathrm{~F}$ & 11 & Idiopathic & GH & GH & 1.9 & 14.6 & 0.4 & 19.7 \\
\hline 3 & $M$ & 14 & Idiopathic & GH & $\mathrm{GH}$ & 4.6 & 19.7 & 0.7 & 47.9 \\
\hline 4 & $\mathrm{~F}$ & 7.3 & Idiopathic & GH & GH & 4.1 & 39.7 & 0.5 & 23.4 \\
\hline 5 & $\mathrm{~F}$ & 13.5 & Idiopathic & $\mathrm{GH}, \mathrm{ADH}$ & GH & 10.5 & 41.9 & 3.1 & 85.3 \\
\hline 6 & $\mathrm{~F}$ & 12 & Idiopathic & $\mathrm{GH}$ & $\mathrm{GH}$ & 11.6 & 26.2 & 0.7 & 33.6 \\
\hline 7 & M & 11 & Septooptic dysplasia & GH, TSH & $\mathrm{GH}, \mathrm{T}_{4}$ & 9.7 & & 0.8 & 17.4 \\
\hline 8 & $\mathbf{M}$ & 13 & Idiopathic & GH, TSH, LH, FSH & $\mathrm{T}_{4}$ & 5.9 & 13 & 0.06 & 11.5 \\
\hline 9 & $\mathbf{M}$ & 14 & Idiopathic & $\mathrm{GH}, \mathrm{LH}, \mathrm{FSH}$ & NONE & 5.7 & 13.5 & & \\
\hline 10 & $\mathbf{F}$ & 14 & $\begin{array}{l}\text { Postremoval } \\
\text { craniopharyngioma }\end{array}$ & GH, TSH, LH, FSH & $\mathrm{T}_{4}$ & 4.6 & 10.5 & 0.2 & 6.0 \\
\hline 11 & $\mathbf{F}$ & 12 & Septooptic dysplasia & GH, TSH, ADH & $\mathrm{GH}, \mathrm{T}_{4}$, DDAVP & 7.3 & 4.9 & $<0.3$ & $<0.3$ \\
\hline 12 & $\mathbf{F}$ & 17 & $\begin{array}{l}\text { Postremoval } \\
\text { craniopharyngioma }\end{array}$ & $\begin{array}{l}\text { GH, TSH, ADH, LH, } \\
\text { FSH }\end{array}$ & $\mathrm{T}_{4}, \mathrm{DDAVP}$ & 3.5 & 2.7 & 0.06 & 1.5 \\
\hline 13 & $\mathbf{M}$ & 14 & Idiopathic & GH, TSH, LH, FSH & $\mathrm{T}_{4}$ & 0.8 & 1.4 & 0.24 & 3.4 \\
\hline 14 & $\mathbf{M}$ & 14 & Idiopathic & GH, TSH, LH, FSH & $T_{4}$ & 2.2 & 2.7 & 0.06 & 1.7 \\
\hline 15 & $\mathbf{M}$ & 18 & $\begin{array}{l}\text { Postremoval } \\
\text { craniopharyngioma }\end{array}$ & $\mathrm{GH}, \mathrm{TSH}, \mathrm{LH}, \mathrm{FSH}$ & $\mathrm{T}_{4}$ & 3.2 & 5.1 & 0.06 & 0.7 \\
\hline 16 & $\mathbf{M}$ & 18 & Idiopathic & GH, TSH, LH, FSH & $T_{4}$ & 3.5 & 3.5 & 0.06 & 0.4 \\
\hline
\end{tabular}

* GH, growth hormone; ADH, antidiuretic hormone; $\mathrm{T}_{4}$, L-thyroxine. To convert $17-\mathrm{OHCS}$ from $\mu \mathrm{mol} / 24 \mathrm{~h}$ to mg/24 h, multiply by $0.362 ;$ to convert DOC from nmol/L to ng/dL, multiply by 33.3. Cases $1-9$ have intact ACTH reserve; case 10 has partial ACTH deficiency; cases $11-16$ have severe ACTH deficiency. 
ACTH were collected in chilled glass tubes containing EDTA. Blood samples were immediately centrifuged for separation of plasma and serum, placed into polypropylene vials, and frozen at $-20^{\circ} \mathrm{C}$ until assayed.

Laboratory methods. Samples from an individual were analyzed simultaneously. Serum DOC and F were determined by RIA after chromatographic purification of the sera (12-14). RIA for ACTH was performed using previously described RIA methods (3). The lowest limit of detection was $0.8 \mathrm{nmol} / \mathrm{L}$ for F RIA and $<0.06 \mathrm{nmol} / \mathrm{L}$ for DOC RIA. The intraassay and interassay coefficients of variation for $\mathrm{F}$ and $\mathrm{DOC}$ assays were $5-10 \%$ and $8-15 \%$, respectively. The lowest limit of detection for the ACTH assay was $1.1 \mathrm{pmol} / \mathrm{L}$, and the intraassay and interassay coefficients of variation were $3 \%$ and $5 \%$, respectively. Urinary 17-OHCS was measured by a colorimetric method.

\section{RESULTS}

Responses of serum $F$ and plasma ACTH to CRH administration in control normal subjects are shown in Figures 1 and 2, respectively. The mean baseline $F$ level $(-15$ and $0 \mathrm{~min}$ ) was $359 \mathrm{nmol} / \mathrm{L}$ (range: $110-497 \mathrm{nmol} / \mathrm{L}$ ) in normal subjects and rose to a mean peak of $773 \mathrm{nmol} / \mathrm{L}$ (range: $554-993 \mathrm{nmol} / \mathrm{L}$ ) between 30 and $60 \mathrm{~min}$ after CRH administration (Fig. 1A). The mean baseline ACTH level $(-15$ and $0 \mathrm{~min}$ ) was $5.6 \mathrm{pmol} / \mathrm{L}$ (range: $3.4-10.2$ $\mathrm{pmol} / \mathrm{L}$ ) and rose to a mean peak of $12.6 \mathrm{pmol} / \mathrm{L}$ (range: $6.3-25.2 \mathrm{pmol} / \mathrm{L}$ ) between 15 and $60 \mathrm{~min}$ after CRH administration (Fig. $2 A$ ).

In nine hypopituitary patients with intact $\mathrm{ACTH}$ reserve, as determined by the metyrapone test (cases 1-9, Table 1), the baseline F and ACTH levels were within the normal range (Figs. $1 B$ and $2 B$ ). The mean baseline $F$ level was $304 \mathrm{nmol} / \mathrm{L}$ (range: $110-607 \mathrm{nmol} / \mathrm{L}$ ) and rose to a mean peak of $607 \mathrm{nmol} / \mathrm{L}$ (range: $497-773 \mathrm{nmol} / \mathrm{L}$ ) between 30 and $60 \mathrm{~min}$ in most patients, which was similar to the response in normal subjects (Fig. $1 A$ and $B)$. The mean baseline ACTH level was $6.1 \mathrm{pmol} / \mathrm{L}$ (range: $4.3-10.1 \mathrm{pmol} / \mathrm{L}$ ) and rose to a mean peak response of $11.7 \mathrm{pmol} / \mathrm{L}$ (range: $5.2-22 \mathrm{pmol} / \mathrm{L}$ ) between 15 and $60 \mathrm{~min}$ in most patients. ACTH response to CRH in all except one patient with intact $\mathrm{ACTH}$ secretion was essentially in the normal range (Fig. $2 B$ ). One patient's ACTH response was below the normal range between 30 and $180 \mathrm{~min}$; however, the peak response at $15 \mathrm{~min}$ was in the normal range.

In six severely ACTH-deficient hypopituitary subjects (cases 11-16, Table 1), the baseline serum $F$ level was low (mean/range: $3.3 / 2.8-80 \mathrm{nmol} / \mathrm{L}$ ) compared with the level in control and ACTH-intact hypopituitary patients. The $\mathrm{F}$ response to $\mathrm{CRH}$ administration in this group was lower during the first 15 to $60 \mathrm{~min}$ in all subjects and showed a delay in increase at $90-180 \mathrm{~min}$ in three subjects compared with the response in normal subjects and ACTH-intact hypopituitary patients (Fig. 1C). ACTH
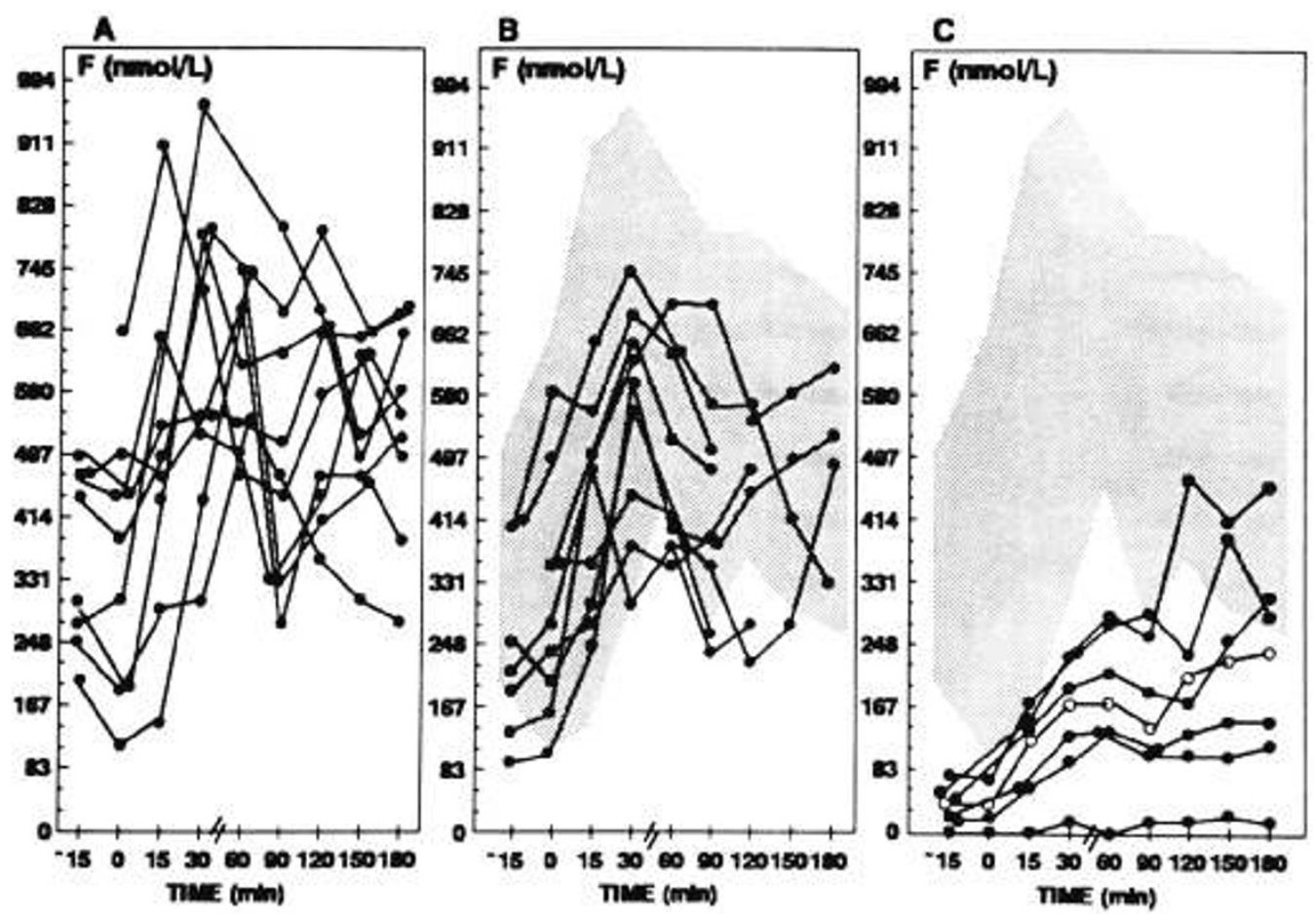

Figure 1. Serum $\mathrm{F}$ response to CRH stimulation in normal subjects and hypopituitary patients. $A$ represents the response in normal subjects; $B$ represents the response in ACTH-intact hypopituitary patients; and $C$ represents the response in ACTH-deficient patients. The shaded area in $B$ and $C$ represents the response in normal subjects. Filled circles indicate severely ACTH-deficient patients, and open circles indicate a patient with partial ACTH deficiency. State of ACTH reserve was determined by a standard metyrapone stimulation test. The lines connect individual values. To convert $\mathrm{F}$ levels from $\mathrm{nmol} / \mathrm{L}$ to $\mu \mathrm{g} / \mathrm{dL}$, divide by 27.6 . 

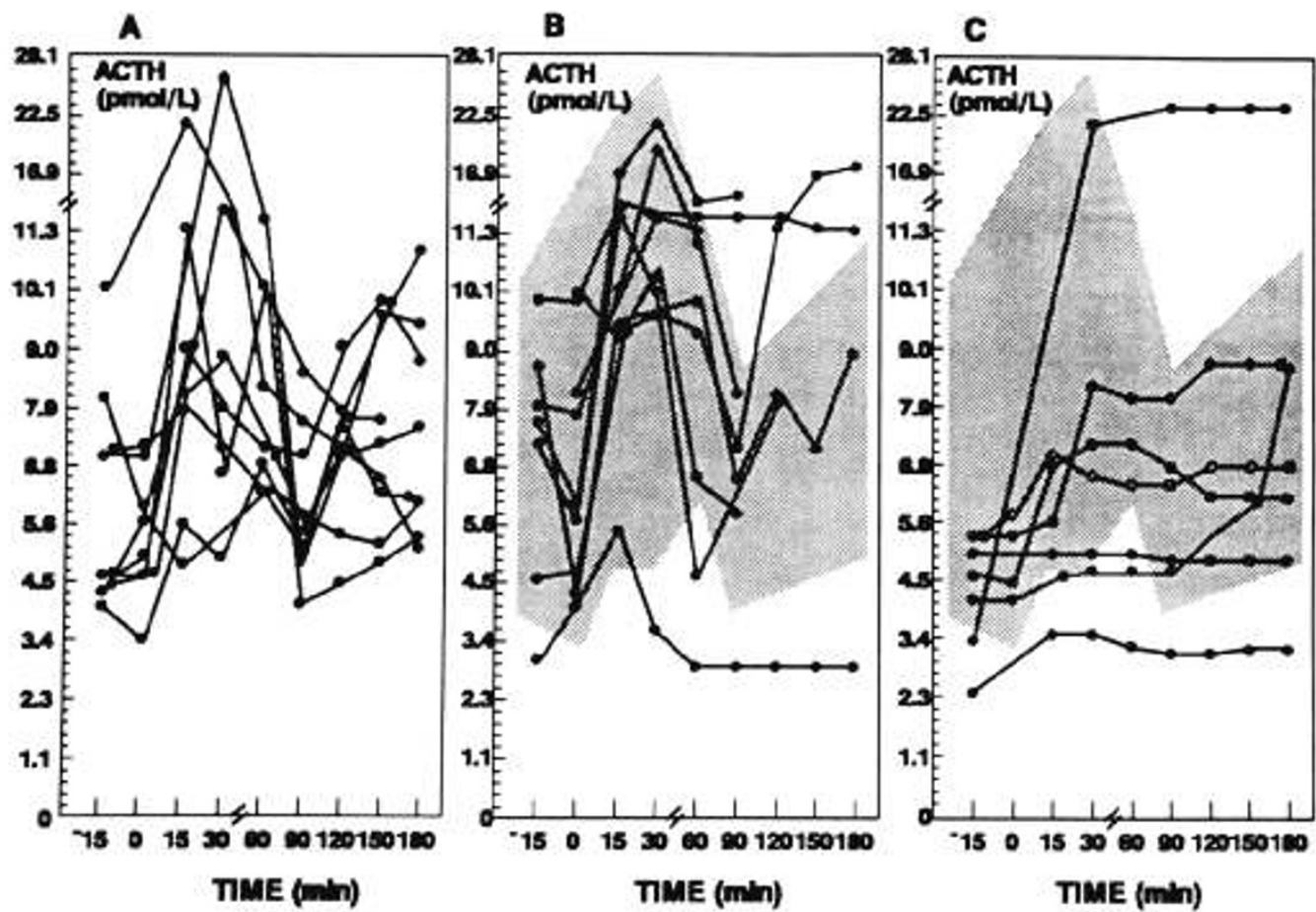

Figure 2. Plasma ACTH response to CRH stimulation in normal subjects and hypopituitary patients. $A$ represents the response in normal subjects; $B$ represents the response in ACTH-intact hypopituitary patients; and $C$ represents the response in ACTH-deficient patients. The shaded area in $B$ and $C$ represents the response in normal subjects. Filled circles indicate severely ACTH-deficient patients, and open circles indicate a patient with partial ACTH deficiency. State of ACTH reserve was determined by a standard metyrapone stimulation test. The lines connect individual values. To convert $\mathrm{ACTH}$ levels from $\mathrm{pmol} / \mathrm{L}$ to $\mathrm{pg} / \mathrm{mL}$, multiply by 4.5 .

levels in these patients rose from a mean baseline of 3.8 $\mathrm{pmol} / \mathrm{L}$ (range: $2.5-5.4 \mathrm{pmol} / \mathrm{L}$ ) to a mean peak of 9.5 $\mathrm{pmol} / \mathrm{L}$ (range: $3.4-24.3 \mathrm{pmol} / \mathrm{L}$ at $15-180 \mathrm{~min}$ ) in response to CRH (Fig. 2C). In these subjects, peak ACTH responses were either noticeably lower (cases 13 and 15), normal (cases 14 and 16), delayed (case 12), or persistently elevated (case 11) compared with ACTH-intact hypopituitary patients and normal subjects.

In one patient (case 10, Table 1) with partial ACTH deficiency, the baseline $F$ level was lower $(39 \mathrm{nmol} / \mathrm{L}$ ) than the levels in ACTH-intact hypopituitary subjects and normal controls; peak $F$ response to $\mathrm{CRH}$ was also low and delayed $(246 \mathrm{nmol} / \mathrm{L}$ at $180 \mathrm{~min}$ ) (Fig. $2 C)$. In this patient, both the peak ACTH response $(7 \mathrm{pmol} / \mathrm{L})$ and the overall ACTH response to CRF were normal (Fig. 2C).

\section{DISCUSSION}

Accurate assessment of the integrity of the hypothalamic-pituitary-adrenal axes requires a test that is sensitive, safe, and practical. No one test as yet fulfills this requirement (15). Often, multiple tests are necessary to unequivocally determine ACTH reserve status. This is of particular concern for children in whom multiple testing is not always practical or safe. In this study, we examined the usefulness of the CRH stimulation test for evaluation of the integrity of the hypothalamic-pituitary-adrenal axes. Based on $F$ response, we found that the CRH stimulation test is a safe and efficient method of determining the ACTH reserve in children with hypopituitarism.
As a standard for comparison, a multiple-dose metyrapone test using urinary 17-OHCS excretion and serum DOC response was used to accurately assess ACTH reserve $(11,16)$. The shorter, more widely used singledose metyrapone test (17) was not used in this study because very mild or subtle forms of ACTH deficiency may not be detected by this test (15) and reported data of normal subjects were limited to adults $(18,19)$. The longer, multiple-dose metyrapone test would allow a more definitive assessment of ACTH reserve status for comparison with CRH testing. CRH testing was performed during the afternoon hours, because it has been established that the greatest incremental $F$ response to $\mathrm{CRH}$ occurs during the afternoon hours $(20,21)$. The normal and low baseline $F$ levels in hypopituitary patients corroborated with the ACTH reserve status determined by metyrapone test as being an ACTH-intact or -deficient state, respectively. Thus, the baseline 1300-h F levels seem to be useful for assessing ACTH reserve status. The CRH-stimulated $F$ level in patients with an intact ACTH reserve, as determined by the metyrapone test, was similar to that of normal controls and corroborated previous reports of CRH stimulation in normal subjects (21). The peak $F$ response in both normal and ACTH-intact hypopituitary patients occurred between 30 and $60 \mathrm{~min}$ after CRH administration. In all ACTHdeficient subjects, including severely and partially ACTH-deficient patients, the $F$ response to $\mathrm{CRH}$ was below the normal range within the $60-\mathrm{min}$ response and a 
few subjects had delayed peaks between 90 and $180 \mathrm{~min}$. This $\mathrm{F}$ response was comparable to the urinary $17-\mathrm{OHCS}$ and serum DOC responses to metyrapone administration in these patients. Thus, $F$ response evaluation during the first hour (at 30 and $60 \mathrm{~min}$ ) after $\mathrm{CRH}$ administration is useful in distinguishing ACTH deficiency from ACTHintact hypopituitarism.

The plasma ACTH response to $\mathrm{CRH}$ in hypopituitary patients was variable and did not correspond with the urinary $17-\mathrm{OHCS}$ or serum DOC response to metyrapone administration in any $\mathrm{ACTH}$ reserve status group. In ACTH-intact hypopituitary subjects, the peak ACTH response to $\mathrm{CRH}$ was observed at 15-60 min and was similar to that of controls. Several investigators have reported a similar plasma $\mathrm{ACTH}$ response to $\mathrm{CRH}$ in normal subjects $(20,22)$. The variable ACTH response to CRH in either partially or severely ACTH-deficient hypopituitary subjects may reflect the various pathologic sites of ACTH deficiency. Poor ACTH response to CRH stimulation in subjects with secondary adrenal insufficiency has been associated with primary pituitary dysfunction (6), and persistently elevated or delayed ACTH responses to $\mathrm{CRH}$ in $\mathrm{ACTH}$-deficient subjects have been interpreted as "primary CRH deficiency" $(4,6,7)$. A low ACTH response to CRH in two ACTH-deficient subjects with either resected craniopharyngioma or idiopathic panhypopituitarism in our study suggests primary pituitary failure. Persistently elevated, normal, or delayed ACTH response to $\mathrm{CRH}$ in five patients with idiopathic hypopituitarism, septooptic dysplasia, or resected craniopharyngioma was suggestive of partial CRH deficiency. Synergism between vasopressin and CRH has been documented $(23,24)$. Two of the patients with ACTH deficiency received maintenance DDAVP treatment at the time of CRH testing; their ACTH response was elevated or delayed, although their $\mathrm{F}$ response was low. ACTH response to $\mathrm{CRH}$ in these patients was not likely influenced by DDAVP, because DDAVP does not bind to the receptor for vasopressin and does not stimulate ACTH release (25).

Neither the multiple-dose nor the single-dose metyrapone test distinguishes a hypothalamic versus pituitary cause of ACTH deficiency, and either dose may cause symptoms of adrenal insufficiency during the test. Furthermore, the conventional multiple-dose metyrapone test is cumbersome, requiring urine collections and hospitalization. The insulin provocative test entails risk of severe hypoglycemia in hypopituitary patients. The adrenal stimulation test by exogenous $\mathrm{ACTH}$ administration is a simple, practical method of screening for adrenal insufficiency. It is, however, at best an indirect method of assessing hypothalamic-pituitary-adrenal axis function, and patients with mild or early-stage ACTH deficiency may respond normally to the exogenous ACTH stimulation $(15,26)$.

Simultaneous evaluation of $F$ and $A C T H$ response during the first hour of the $\mathrm{CRH}$ stimulation test may be advantageous in the assessment of ACTH reserve as well as differentiation of hypothalamic versus pituitary causes of ACTH deficiency. This differentiation may be important, inasmuch as restoration of normal $F$ secretion was possible in corticotropin-sparing $\mathrm{CRH}$-deficienct patients by administration of $\mathrm{CRH}(27,28)$, and the potential for a $\mathrm{CRH}$ analog as a therapeutic agent exists for CRHdeficient hypopituitary patients. The outpatient testing method and safety of the CRH test are advantageous in its use in children for evaluation of ACTH reserve. Thus, we conclude that evaluation of $F$ response to $\mathrm{CRH}$ is a useful and safe screening test for ACTH reserve in addition to providing information regarding the hypothalamic versus pituitary etiology for ACTH deficiency.

\section{REFERENCES}

1. Muller OA, Stalla GK, van Werder K 1980) Corticotropin releasing factor: a new tool for the differential diagnosis of Cushing's syndrome. J Clin Endocrinol Metab 57:227-229

2. Muller OA, Hartwimmer J, Hauer A, Kaliebe T, Schopohl J, Stalla GK, van Werder K 1986 Corticotropin-releasing factor (CRF): stimulation in normal controls and in patients with Cushing's syndrome. Psychoneuroendocrinology 11:49-60)

3. Chrousos GP, Schulte HM, Oldfield EH, Gold PW, Cutler Jr GB, Loriaux DL 1984 The corticotropin-releasing factor stimulation test: an aid in the evaluation of patients with Cushing`s syndrome. N Engl J Med 310:622-626

4. Fukata J, Nakai Y, Imura H, Abe K. Aono T, Demura H, Fujita T, Hibi I, Ibayashi H, Igarashi M, Irie M, Izumi K, Kageyama N, Kato K, Kumahara Y, Matsuzaki F, MatsuKura S, Miyai K. Mori S, Nakagawa K, Nakajima $H$ Niimi M, Ogata E, Saito S, Shimizu N, Shizume K. Takahara J, Takakura K, Tomita A, Uozumi T, Wakabayashi I, Yanaihara N, Yoshimi T, Yoshinaga K 1988 Human corticotropin-releasing hormone test in normal subjects and patients with hypothalamic, pituitary or adrenocortical disorders. Endocrinol Jpn 35:491-502

5. Witz L, Josefsberg Z, Kaufman H. Laron Z 1988 When should hydrocortisone therapy be instituted in children with hypopituitarism? Am J Dis Child 142:881-883

6. Schulte HM, Chrousos GP. Avgerinos P, Oldfield EH, Gold PW, Cutler Jr GB, Loriaux DL 1984 The corticotropin-releasing hormone stimulation test: a possible aid in the evaluation of patients with adrenal insufficiency. J Clin Endocrinol Metab 58:1064-1067

7. Copinschi G, Wolter R, Bosson D, Beyloos M, Golstein J, Franckson JRM 1984 Enhanced ACTH and blunted cortisol responses to corticotropinreleasing factor in idiopathic panhypopituitarism. J Pediatr 105:591-593

8. Tsukada T, Nakai $Y$, Koh T, Tsujii S, Inada M, Nishikawa M, Shinoda $H$, Kawai I, Takezawa N, Imura H 1984 Plasma adrenocorticotropin and cortisol responses to ovine corticotropin-releasing factor in patients with adrenocortical insufficiency due to hypothalamic and pituitary disorders. J Clin Endocrinol Metab 58:758-760)

9. Gold PW, Kling MA, Khan I, Calabrese JR, Kalogeras K, Post RM, Avger inos PC. Loriaux DL. Chrousos GP 1987 Corticotropin releasing hormone: relevance to normal physiology and to pathophysiology and differential diag. nosis of hypercortisolism and adrenal insufficiency. In: Nerozzi D, Goodwin FK, Costa E (cds) Hypothalamic Dysfunction in Neuropsychiatric Disorders. Raven Press, New York, pp 183-200

10. Muller OA. Stalla GK, van Werder K 1987 Corticotropin-releasing factor in humans. Hormone Res 25:185-198

11. Hung W, August GP, Glasgow AM 1983 Adrenal gland. In: Hung W, Augus GP, Glasgow AM (eds) Advanced Textbook of Pediatric Endocrinology. Medical Examination Publishers, New York, pp 204-279

12. Pang S, Wang M, Jeffries S, Riddick L, Clark A, Estrada E 1992 Normal and elevated $3 \alpha$-androstanediol glucuronide concentrations in women with various causes of hirsutism and its correlation with degree of hirsutism and androgen levels. J Clin Endocrinol Metab 75:243-248

13. Pang $S$, MacGillivray $M$, Wang $M$, Jeffries $S$, Clark $A$, Rosenthal 1 , Wiegensberg M, Riddick L $19913 \alpha$-androstanediol glucuronide in virilizing congenital adrenal hyperplasia: a useful serum metabolic marker for integrated adrenal androgen secretion. J Clin Endocrinol Metab 73:166-174

14. Pang S. Levine LS, Lorenzen F, Chow D, Pollack M, Dupont B, Genel M, New Ml 1980 Hormonal studies in obligate heterozygotes and siblings of patients with $11 \beta$-hydroxylase deficiency congenital adrenal hyperplasia. J Clin Endocrinol Metab 50:586-589

15. Streeten DHP, Anderson Jr GH, Dalakos TG, Seeley D, Mallov JS, Eusebio R, Sunderlin FS, Badawy SZA, King RB 1984 Normal and abnormal function of the hypothalamic-pituitary-adrenecortical system in man. Endocr Rev 5:371-394

16. Pang S, Legido A, Levine LS, Temeck JW, New MI 1987 Adrenal androgen response to metyrapone, adrenocorticotropin, and corticotropin-releasing hormone stimulation in children with hypopituitarism. J Clin Endocrinol Metab 65:282-289 
17. Spark RF 1971 Simplified assessment of pituitary adrenal reserve: measurement of serum 11-deoxycortisol and cortisol after metyrapone. Ann Intern Med 75:717-723

18. Liddle GW 1981 The adrenals. In: Williams RH (ed) Textbook of Endocrinology. WB Saunders, Philadelphia, pp 249-292

19. Dickstein G, Lahav M, Orr ZS 1986 Single-dose metyrapone test at $06.00 \mathrm{~h}$ : an accurate method for assessment of pituitary-adrenal reserve. Acta Endocrinol 112:28-34

20. DeCherney GS, DeBold CR, Jackson RV, Sheldon WR, Island DP, Orth DN 1985 Diurnal variation in the response of plasma adrenocorticotropin and cortisol to intravenous ovine corticotropin-releasing hormone. J Clin Endocrinol Metab 61:273-279

21. Schulte HM, Chrousos GP, Oldfield EH, Gold PW, Cutler GB, Loriaux DL 1985 Ovine corticotropin-releasing factor administration in normal men: pituitary and adrenal responses in the morning and evening. Horm Res 21:69-74

22. Hermus ARMM, Pieters GFFM, Smals AGH, Benraad ThJ, Kloppenborg PWC 1984 Plasma adrenocorticotropin, cortisol, and aldosterone responses to corticotropin-releasing factor: modulatory effect of basal cortisol levels. J Clin Endocrinol Metab 58:187-191

23. DeBold CR, Sheldon WR, DeCherney GS, Jackson RV, Alexander AN, Vale W, Rivier J, Orth DN 1983 Arginine vasopressin potentiates adrenocorti- cotropin release induced by ovine corticotropin-releasing factor. J Clin Inves 73:522-538

24. Lamberts SWJ, Verleun T, Oosterom R, DeJong F, Hackeng WHL 1984 Corticotropin-releasing factor (ovine) and vasopressin exert a synergistic effect on adrenocorticotropin release in man. J Clin Endocrinol Metab 58:298303

25. Malerbi DA, Mendonca BB, Liberman B, Toledo SPA, Corradini MCM, Cunha-Neto MB, Fragoso MCBV, Wajchenberg BL 1993 The desmopressin stimulation test in the differential diagnosis of Cushing's syndrome. Clin Endocrinol 38:463-472

26. Doar JWH, Wynn V, Webb PJ 1970 Comparison of tests of hypothalamopituitary-adrenocortical function in pituitary disease. J Endocrinol 48:47-54

27. Avgerinos PC, Schurmeyer TH, Gold PW, Tomai TP, Loriaux DL, Sherin RJ, Cutler Jr GB, Chrousos GP 1986 Pulsatile administration of human corticotropin-releasing hormone in patients with secondary adrenal insufficiency: restoration of the normal cortisol secretory pattern. J Clin Endocrinol Metab 62:816-821

28. Pang S, Harbison M, Nemery R 1987 Down regulation of ACTH secretion in hypopituitarism from prolonged administration of corticotropin releasing hormone. Program of the 69 th Meeting of the Endocrine Society, Indianapolis, p 142(abstr) 